\title{
An In-Depth Thematic Analysis of Customer Driven Factors Influencing the Purchase Decisions of Guests in Four and Five Star Hotels in Kenya
}

\author{
Antoneta $\mathrm{Njeri}^{1}$, Edwin Odhuno ${ }^{2}$ \& Oscar Ouma Kambona ${ }^{1}$ \\ ${ }^{1}$ Department of Eco-Tourism, Hotel and Institution Management, Maseno University, Maseno, Kenya \\ ${ }^{2}$ School of Business and Economics, Mount Kenya University, Thika, Kenya \\ Correspondence: Antoneta Njeri, Department of Eco-Tourism, Hotel and Institution Management, Maseno \\ University, Maseno, Kenya. E-mail: antonettanjeri@gmail.com/antonettanjeri@yahoo.com
}

\author{
Received: March 5, 2015 Accepted: October 16, 2015 Online Published: November 30, 2015 \\ doi:10.5539/ijms.v7n6p61 URL: http://dx.doi.org/10.5539/ijms.v7n6p61
}

\begin{abstract}
It is apparent that Kenya's tourism marketing strategies are not effective. One way for hospitality facilities in the country to stay ahead of competitors is by addressing the ever changing needs of their guests. Various factors also influence the purchase decisions of guests in four and five star hotels. These factors should nonetheless form the bases of the marketing strategies of the hotels. This study consequently explored the purchase decisions of guests in the hotels with a view of enhancing the tourism performance of the country. The guests, who were interviewed, identified the atmosphere, hospitality, food, facilities, amenities, location, accessibility, price, value, discounts and security as being the key factors behind their purchase decisions. These should subsequently be addressed by hospitality marketers in the country.
\end{abstract}

Keywords: Customer driven factors, hotels, Kenya

\section{Introduction}

There is increased international competition between destinations and hotels (Elaver, Tari, \& Pereira, 2006) and it is apparent that Kenya's tourism marketing strategies are ineffective and need to be adjusted in order for the nation to be able to successfully compete both locally and internationally. Kenya is a renowned tourist destination competing with countries such as Egypt, Algeria, Tunisia, South Africa, Seychelles and Tanzania. This competition calls for strategies that would give the country advantages over its competitors. Changing times have dictated that the country changes its marketing strategies. This is due to the impact of forces such as politics, economic cycles, socio-cultural trends, technological changes, demographic shifts, globalisation and multi-culturalism. However, Kenya has been slow in adjusting to some of these changes and adopting competitive marketing strategies. This is evidenced by the growth of tourism in the competitor countries which has not been seen in the Kenyan tourism industry. Furthermore, accommodation and dining are essential elements and aspects of the tourism product and these poor marketing strategies could easily trickle down to hotels and restaurants which offer these services. Hospitality practitioners thus need to understand their customers' purchase behaviours and meet their desires. Pursuing marketing strategies which do not take into consideration what matters most to the customer would lead to poor business performance since the establishment will not be able to attract customers and sustain operations.

\section{Literature Review}

\subsection{The Hospitality and Tourism Industries}

The term "hospitality" means to cater to the needs of guests who are away from their homes by providing food, shelter and accommodation (Dittmer \& Griffin, 1993). Dittmer and Griffin consequently described the hospitality industry as an industry which provides accommodation, food, entertainment and other related products and services to travellers and tourists. The tourism industry then again consists of companies, facilities and ancillary activities used to cater to tourists travelling away from their usual places of residence (Jeffries, 2001). Page (2006) defined tourism as "the activities of persons travelling to and staying in places outside their usual environment for not more than one consecutive year for leisure, business and other purposes not related to 
the exercise of an activity remunerated from within the place visited". Tourism is promoted by travel and people are motivated to tour for sightseeing, leisure, sporting, shopping, business, education, reunions, health and religion (Andrews, 2010) among other reasons.

\subsection{Marketing Hospitality Firms}

Previous studies, for example, Williams (2006) have shown that marketing and promotion are important in hospitality development. Modern trends all the same call for creativity on the part of hospitality marketers who must always strive to keep abreast with the changing technology and customers' needs, expectations, values (Kandampully, 2006), tastes and preferences. Past literature reveals that hotels face challenges in creating effective marketing strategies (Negi, 2002) perhaps due to lack of competent marketing staff and insight into the ever changing hospitality environment including political, market, technological, ecological and socio-cultural forces. But scholars have suggested ways of overcoming these challenges. For example, Kara, Kaynak and Kucukemiroglu (1995) in studying marketing strategies for fast foods posited that these strategies should address customers' perceptions, preferences and determinants of their purchase decisions. This is because customers usually form perceptions of businesses which then dictate their choices. So marketers should understand the factors which influence their purchase decisions and emphasize them in their strategies.

\section{Research Methodology}

\subsection{Population and Sampling Technique}

Census technique, in which all the subjects in the population get the chance to be respondents, was used to get customers who participated in the study. The study therefore focused on all visitors who frequented the hotels during the nine months that it was conducted. Census technique enabled as many respondents as possible to be targeted thus increasing accuracy while controlling bias and the setbacks of using convenience sampling. The study was carried out during the peak and off peak seasons of tourism between the months of May 2014 and January 2015 in order to gather data that was reflective of the industrial trends and so avoid bias. A total of twenty six customers participated in the interviews. Twenty respondents were approached in Mombasa while six were interviewed in Nairobi. The guests were approached at the hotels and at tourist sites such as beaches, museums and national parks in Nairobi and Mombasa. Nairobi and Mombasa were selected as the study areas because all gazetted four and five star hotels in Kenya are located in these regions (The Kenya gazette, 2003). Customers who had spent at least one night in any of the hotels during the study period were targeted.

\subsection{Research Instrument and Data Analysis Techniques}

The interviews asked them to explain the factors which they would consider important when deciding to visit a four or five star hotel and that should subsequently be addressed by the marketing strategies of the hotels. Qualitative data compiled from the interviews was analysed and presented using thematic analysis and the NVIVO 10 software. Thematic analysis is a qualitative research data analysis method that identifies themes which emerge from data (Kombo \& Tromp, 2006).

\section{Results}

\subsection{Demographics Characteristics of Respondents}

A majority of the respondents $(23,88.00 \%)$ were Kenyans, $1(4.00 \%)$ was a Somali, 1 (4.00\%) Ugandan and 1 $(4.00 \%)$ Sudanese. The respondents were aged between 20 and 55 years with a mean age of 35.43 years. 15 $(58.00 \%)$ respondents were male while the other $11(42.00 .0 \%)$ were female.

\subsection{Results from Interviews - A Thematic Analysis}

Since hotels in Kenya cannot neglect their customers, their marketing strategies should match their guests' needs. Seven factors which the guests indicated greatly influenced their purchase decisions and should therefore be addressed by the marketing strategies of four and five star hotels were identified. The nodes representing these factors were labelled; "atmosphere", "facilities and amenities", "food", "hospitality standards", "location and accessibility", "price, value and discounts" and "security".

The first node which was named "atmosphere" addressed the environment, ambience, crowding and appearance of staff, other guests and the hotel's exterior. Some guests preferred peaceful, quiet, relaxing, calm, cool and beautiful environments.

“...atmosphere should be cool and relaxing so as to create a good holiday get away. This will ensure that I have peace of mind and enough time to relax and enjoy..." (Kenyan, Male, 24) 
“...atmosphere should be peaceful. When I visit the hotel, my intention is to go and relax after many working months so I would expect the place not to be too noisy and again they should play soft music that does not disrupt the relaxing mood..." (Kenyan, Female, 42)

“...it should be free from noise as this creates a calm atmosphere which will enable me to concentrate on important matters such as meetings with fellow businessmen and clients. In addition to this, the hotel should be clean and tidy so as to reduce cases of infections..." (Kenyan, Male, 30)

Several felt that the settings including layout and appearance should be appealing.

“...the layout and appearance gives a good image of the business. The flower beds should be well maintained and the walls should also have appealing and attractive decorations and colours..." (Kenyan, Female, 32)

“...nobody would like to be in a place where things are placed anyhow without a systematic order. I believe what the eyes perceive says a lot about the hotel and its management..." (Kenyan, Female, 52)

Crowding and the appearance of other customers too formed crucial aspects of the atmosphere.

“...crowding particularly at the front office and the appearance of other customers is important since their behaviour and appearance influences other customers...at times you will meet other guests whose behaviour and appearance will make you wonder..." (Kenyan, Female, 52)

The appearance of staff particularly their neatness also mattered to a few.

“...appearance of staff is important though it will only be determined once you arrive at the hotel. Employees should generally be neat..." (Kenyan, Male, 30)

“...the staff should not be noisy...” (Ugandan, Male, 36)

The appearance of the hotel's exterior as reflected by the grounds, landscapes and built environments further influenced the guests' choices.

"...I would not visit a facility that is not attractive or appealing enough for me in terms of the appearance of the grounds. The grounds should be beautiful and well kept..." (Ugandan, Male, 36)

“...the appearance from outside and also inside, from how the lawns are maintained to the colours and materials used in decorating. They should be of high quality so as to satisfy that prestigious look..." (Kenyan, Male, 23)

"...it was the external appearance as shown on the picture I was given that made me visit this hotel..." (Kenyan, Female, 42)

"...the hotel should be advertised heavily so that the locals can learn about it...the quality of the advertisement and its impact and effect on me also influenced my decision..." (Somali, Male, 48)

The second node named "facilities and amenities" revealed the importance of information technology (IT), parking space, tour guiding facilities and quality of amenities that would enhance service delivery and the stay.

“...I prefer hotels which use current technology. As we all know technology keeps changing, hence I believe that the hotel should strive to automate its functions as this ensures accuracy of information and reduces a lot of paperwork. Paperwork may lead to loss of vital documents making it difficult for customers to have evidence whenever they want to make a claim. The hotel too should provide stable WIFI services..." (Kenyan, Female, 42)

Some altogether had mixed reactions on the value of transportation facilities.

“...the value of parking depends on where you have travelled from. One may use a taxi. For example, if you travel from Nairobi to Mombasa, you may leave your car at home and instead use a taxi while in Mombasa..." (Kenyan, Male, 29)

“...they should offer transport services to pick and drop guests around the country...tour guiding facilities for non citizens who are not familiar with the environment and activities in Kenya are important..." (Sudanese, Male, 37)

Others drew attention to amenities which they stressed should be of high quality.

"...due to the fact that I have paid a lot of money to be in the hotel, I expect that to be translated in their facilities in terms of the room amenities and amenities in the area of relaxation..." (Kenyan, Female, 32) 
“...I prefer accommodation with unique amenities such as large beds and superior quality accommodation..." (Sudanese, Male, 37)

“...quality of rooms should make me feel at home..." (Kenyan, Male, 40)

Several reported that they liked clean environments.

“...linen and other accessories in the room should be clean enough..." (Kenyan, Male, 40)

“...table cloths, towels and beddings used in the hotel should be maintained with high levels of cleanliness and again the dining tables should be clean as well so as to ensure that customers do not contract diseases while staying in the hotel..." (Kenyan, Female, 42)

The third node named "food" revealed that many guests valued meals which were unique, nutritious, safe, of high quality and of various types.

"...the food offered should be unique and there should be a variety of meals which are appetizing and of high quality..." (Ugandan, Male, 36)

“...when visiting a four or five star hotel, I would go to one that has variety of cultural foods as most of us rarely prepare these meals at our homes so this creates a good opportunity for me to take them and have a feel of what other communities have to offer...” (Kenyan, Male, 24)

However, there was agreement amongst some that guests had little control over food safety.

"...food safety is important though the customer cannot influence it since the food may even be over spiced in order to conceal any abnormalities or failures..." (Kenyan, Female, 52)

But, a few talked about the price of the meal being an indication of its quality.

"...I would visit a hotel where I am assured that the foods and drinks are of high quality to guarantee and match the amount of money that I am going to spend..." (Kenyan, Male, 20)

“...meals should be of high quality which will make them worth the prices being charged. They [meals] should be of a balanced diet so as to keep the customers health in check..." (Kenyan, Female, 42)

The fourth node named "hospitality" reflected guests' desires to be attended to by employees who are fast, reliable, welcoming, courteous, polite, honest, skilled and knowledgeable.

“...employees should have good communication skills and also be polite to the customers. I would also choose a hotel whose employees are knowledgeable about the hotel and the whole hospitality industry at large..." (Kenyan, Male, 25)

“...it being a hospitality industry, staff should be courteous and the receptionists should treat the customer with respect and courtesy. They should also be enlightened about the services that the hotel offers to avoid misleading the customer..." (Kenyan, Female, 32)

“...staff members should be welcoming, courteous and respond to customers orders promptly. This is more especially when I am visiting for business functions where speed really becomes a factor to consider..." (Kenyan, Male, 24)

“...employees should be well trained as this equips them with adequate skills and knowledge of carrying out their functions in a professional manner. They also learn to take care of visitors properly without having the greed to steal from them...” (Kenyan, Male, 40)

Service speed too emerged as an important aspect of the hotel experience for some guests.

“...the services should be in terms of modern hotel services and amenities as this will enable to create the most special experience of the hotel. In a bid to deliver these services, the hotel staff should also respond to customers' requests promptly as this instils confidence among customers thus creating a reputable image..." (Kenyan, Male, 55)

“...services should be fast in terms of service delivery. There shouldn't be long procedures in the time taken to check in. Requests should be responded to on time. Moreover, the staff members should have relations skills so that they can be in a position to address visitors in a courteous and respectable manner..." (Sudanese, Male, 37)

One guest gave an account of an experience in a hotel which showed dissatisfaction.

“...I once visited a five star hotel which had slow service speed at the reception. It took about an hour for me to get a response to an enquiry that I placed at the reception desk. As a result of this incident I 
concluded that the employees in that hotel were not reliable. I also noticed that domestic tourists were being treated worse than foreigners who were being given more attention in treatment and service..." (Kenyan, Female, 42)

"...I also noticed that locals were being treated unfairly as compared to foreigners...they would be welcomed, received and attended to faster and with more attention..." (Kenyan, Female, 32)

The fifth mode labelled "location and accessibility" showed that a number of guests were attracted to hotels which were situated near important attractions such as beaches while others thought that hotels in town centres would not be appealing.

“...when visiting Coastal Kenya, I expect the hotel to be located next to the beach particularly when the visit is for leisure purposes..." (Kenyan, Female, 42)

"...I prefer areas adjacent to the beach so that I can indulge in water sports... sporting activities such as scuba diving are important at the Coastal Kenya..." (Sudanese, Male, 37)

"...I would opt for a hotel which is located away from the town centre as town centres are prone to traffic jams and congestion of people..." (Kenyan, Male, 24)

“...I would not want to spend a lot of time trying to figure out where a hotel is located and also as result of breakdown of the vehicle due to inaccessible roads..." (Kenyan, Male, 25)

The following extracts also demonstrated guests mixed reflections on accessibility.

"...the hotel has to be accessible since I would like to use my personal car, I would therefore choose a hotel with good road networks, making it easily accessible without causing damage to the vehicle as this would raise the cost of repair and maintenance..." (Kenyan, Male, 20)

“...I believe that a five star hotel should be located where transport infrastructures are well developed, this creates convenience and saves the cost of fuel used in the car. Again, it should be away from the town centre as this reduces congestion of people and vehicles. This in turn creates a cool atmosphere..." (Kenyan, Male, 23)

“...the location should be accessible via any means of transport, be it public or private..." (Somali, Male, 48)

"...some hotels are too interior. But I would still visit them regardless of their accessibility as long as it satisfies some of the factors that attract me to it..." (Kenyan, Male, 29)

Convenience and parking were moreover mentioned by some guests.

“...being a business person, I would prefer a hotel which has clearly defined its operating business hours as this will enable me to schedule my daily activities in a convenient way. This will also prevent me from being at loggerheads with the security and management..." (Kenyan, Female, 32)

"...most of the times, I always drive myself to the various seminars and conferences that I attend. I also use my car when going on vacation. Therefore, I would visit a hotel where there is adequate parking space. This ensures that I do not have to pay extra charges outside the hotel..." (Kenyan, Female, 42)

The sixth node named "price, value and income" indicated what the vast majority of guests thought of prices. The examples given below showed that most of them felt that the hotels were overpriced thus limiting their purchase frequencies.

“...the economy and my level of income will determine my choice in relation to price, value and the benefits given. The prices in four and five star hotels are quite high for the locals. They should be reduced at low peak to prices that the locals can afford so that they too may experience the feeling of a five star hotel...however I would visit as a corporate guest attending corporate functions but not as an individual due to the high prices and affordability..." (Kenyan, Male, 29)

“...prices in these hotels are too high for domestic tourists and the locals though when an organization sponsors the guests then the guest will pay little attention to factors such as the price and value of the package..." (Kenyan, Male, 30)

"...most four and five star hotels in Kenya are overpriced particularly to locals. That is why there are constant price reductions for meals and rooms..." (Kenyan, Female, 52).

Others nonetheless appreciated the high prices. 
“...prices in four and five star hotels are supposed to be high in order to keep in line with competitors..." (Kenyan, Female, 42)

"...prices may be too high in these hotels but I would still visit the facilities since I would be well aware that any four or five star hotel will have such high prices..." (Kenyan, Male, 55)

"...I would go to one with highly priced products because I believe that quality and prices go hand in hand. I would find it strange if a high quality hotel priced its products cheaply. I would actually question the quality levels..." (Kenyan, Female, 32)

Value too seemed important to the guests.

"...I would visit a hotel which guarantees maximum value for the money by providing products which are of high quality..." (Kenyan, Male, 25)

"...I would choose a hotel where I would be assured of deriving maximum value for the money I am going to spend. I would not like to be in a place where I would feel short-changed as a result of paying high prices for poor services..." (Kenyan, Male, 23)

"...I have a passion for helping the less fortunate in the society, as I am currently in Kenya taking part in charitable activities. We are helping children from marginalised areas to attend school by giving them scholarships. Hence before visiting any hotel or firm, I consider if they engage charitable organizations in a bid to give back to society. Hence the one with this factor is a plus for me..." (Kenyan, Female, 52).

"...I have seen guests who visit particular hotels which observe CSR since it is in line with their profession in environmental conservationism..." (Sudanese, Male, 37)

Some moreover spoke highly of loyalty programs.

“...being a business man, I would opt for one which gives discounts to its regular customers since I would visit the place several times in a year with my employees and business partners. This will help maintain my loyalty to the hotel..." (Kenyan, Male, 25)

"...I would consider if the business offers discounts to customers who frequently visit the hotel. This is because I normally take my employees for seminars and conferences like four times a year. Therefore, I would highly appreciate where the prices would be charged fairly as a result of me being a loyal customer..." (Kenyan, Male, 40)

The seventh node named "security" reflected their views on insecurity in the country due to terrorism and abductions.

"...this aspect [security] tends to be most important to me due to the current situation in the country in relation to terrorism and kidnapping of tourists..." (Kenyan, Male, 40)

"...following the security threats facing the country, I would choose a hotel which ensures maximum security to its customers by having enough check points and qualified security guards..." (Kenyan, Male, 23)

“....security is paramount keeping in mind the recent terror threats and also cases of visitors being kidnapped. The hotel should have adequate security measures put in place to guarantee customer safety..." (Kenyan, Female, 42)

“....in the recent times, our country has seen cases of tourist abductions and levels of terrorism have been on the rise, thus the hotel should have adequate security checks and equipment in order to minimise criminal risks. This will enable me to have peace of mind when I am in the hotel..." (Kenyan, Male, 20)

\section{Discussion}

International hotel managers need to realise that in today's competitive global environment, there is need to constantly respond to guests as they determine and redefine their needs since they can help them determine aspects in need of improvement. Guests in four and five star hotels in Nairobi and Mombasa were interviewed in order to update information on their purchase decisions and the hotels' marketing strategies. This is because there is no better way to investigate these factors than by simply asking the guests.

Most respondents were Kenyans with the rest being Ugandan, Sudanese and Somali. Their mean age was 35.43 years, but the youngest was 20 years old and the oldest 55 . The sample was predominantly male. Seven main determinants of guests' choices were established; atmosphere, facilities and amenities, food, hospitality standards, location and accessibility, price, value and discounts and security. 
Some guests indicated that they would choose hotels which had superior quality rooms with unique amenities such as large beds, so that they may feel at home. Prior studies have already established that quiet, well maintained rooms, audio-visual equipment, in-room safety box, soothing music, furnishing, internet connection cable, comfortable bed, safe, well equipped bathroom, reasonable room prices, efficient front desk (Poon \& Low, 2005), fridges, hairdryers, parking, cooking, email, children movies (Lockyer, 2005), and amenities such as the "efficiency of room service, variety of food and beverage facilities, quality of food and beverages, reliability of wake-up call, access to information desk and availability of mini bar" (Choi \& Chu, 2000) are some of the accommodation factors influencing travellers' satisfaction.

Several valued clean hotels, particularly clean service linen, beddings and towels. This finding has previously been reported by Lockyer (2002) whose observations based on surveys on managers and guests acknowledged cleanliness of the room as being the most important factor for business guests.

A few liked hotels which had qualified employees who were welcoming, reliable, courteous, polite, friendly and respectful with good communication skills and adequate knowledge of the hotels' products and services and the hospitality industry in general. According to them, reliable employees influence service speed and overall customer satisfaction. These findings can be combined with those of Poon and Low (2005) who highlighted the value of service speed and the friendliness, courtesy, pleasantness and language proficiency of staff. Jani and Han (2011) and Walter, Edvardsson and Ostrom (2010) likewise recognised staff friendliness as a significant factor in service encounters at restaurants.

Some thought that the employees treated foreigners better than the residents when receiving and delivering services, thus indicating service unfairness. According to Namkung, Jang, Almanza and Ismail (2009), "service unfairness can be judged by examining indicators of service failure such as priority of service, delayed service procedures, high pricing and lack of employee attentiveness". These authors emphasised that "service fairness signifies consumers' perceived fairness within the context of an overall service experience with or without service failures" as reflected by distributive, price, outcome, procedural and interactional justice. In such a case the customer will analyse the cost versus benefit (room and menu prices), final output, the service delivery process (e.g., first come first serve basis) and the employees' attitude (competency, skills, knowledge and training).

Several complained about employees, particularly at the front desk, being unreliable and slow in providing services and responding to their requests. Others also ventured for fast service for the business customer. This supported the view that response time is important in service delivery since it affects customer satisfaction and behavioural intentions (Jones \& Dent, 1994). Service speed could affect customer experiences, where delays contribute to unfavourable experiences. Jones and Dent (1994) emphasised that service speed mattered during arrival, seating, ordering, serving food and drinks and during payment while at the front desk, service delivery speed was important during check-in, check-out, porterage, use of telephone, message delivery and when providing room service. However, an exception to this approach to service can be found in luxurious hotels where the customer accepts slow personalised service which is part of the meal experience and which is done in order to increase the average spend by the guest and justify the high prices charged, as is seen with gueridon service and elite guests (Goodman, 1996).

A few were attracted to hotels which served a variety of unique, high quality meals since these made them feel that the experience was worth the prices charged. Poon and Low (2005) too found that fresh food, hygienic food, variety of food, lounge/bar/pub accessibility and food promotion were food and beverage factors determining travellers' satisfaction.

Some however mentioned that menu items ought to be balanced so as not to harm them. This provided evidence that healthy eating is an added concern to most consumers (Alexander, Gorman, \& Wood, 2010). Global trends confirm that illnesses such as diabetes, obesity and high blood pressure have raised alarms on the value of healthy eating. This finding enhances understanding of why consumers are concerned about the calorie and salt content of meals they consume away from home. It is thus not a surprise that prior studies, such as, Josiam and Foster (2009) have established that menu labelling influences customers' decisions on dining out. Josiam and Foster (2009) maintain that nutritional information on cholesterol, total calories, sugar, carbohydrate, protein, sodium, omega 3-fats, dietary fibre, potassium and the complete ingredient list are the most important information the customers would seek and should thus be provided on menus. The two authors pointed out that addressing the needs of customers who are concerned with nutritional information could give a restaurant competitive advantage. But like Alexander et al., (2010) the authors reported that menu labelling may seem appropriate in fast foods and other popular catering establishments rather than in fine dining restaurants similar 
to those found in four and five star hotels. This is because the restaurants' goals are to make sales and profits rather that to meet the nutritional needs of customers. The researchers felt that menu labelling is an expensive exercise that could interfere with the creativity of the chef and additionally suggested that further research be conducted on the opinions of fine dining restaurant customers on the best ways to label restaurant menus and on the need for menu labelling since it may be found unacceptable in such restaurants.

Several forwarded their concerns about food safety, chiefly the freshness of menu items such as fish, which they thought could be over spiced in order to conceal defects. They went on to attribute this practice to poor customer demand management. Some also highlighted the importance of the cleanliness of the hotel and of items such as table clothes and dining tables, in preventing disease outbreaks. These are clearly problematic in light of Burusnukul, Binkley and Sukalakamala, (2011) who contended that outbreaks of food borne illnesses in the past have drawn attention to food safety in restaurants. Henson et al. (as quoted by Knight, Worosz \& Todd, 2007) had likewise named cleanliness as the most important factor among customers in determining the level of food safety at a restaurant. Walter et al. (2010) further expounded that poor hygiene contributes to unfavourable customer experiences while Knight, Worosz and Todd (2007) on the outset explained that when customers perceive lack of food safety at a restaurant, they tend to look for safer premises.

Others preferred hotels which paid keen attention to ambience, appearance of grounds, appearance of the hotel, levels of noise and the music being played since they contributed to conducive, relaxing and peaceful atmospheres. Hwang, Bendle and Yoon (2012) too noted that music has an influence on customer experiences and spending behaviour. Several moreover explained that the grounds ought to be beautiful and well kept and that the interiors must have colours and materials which are appealing and prestigious thus portraying quality. They also stated that the employees have to be neat and not noisy. Walter et al. (2010) maintained that atmospherics determine customers' decisions to frequent restaurants and guests' perceptions on hotel accommodation. Pedraja and Yagiie (2001) likewise found that the physical environment as portrayed by decorations, sounds and lighting determined restaurant choice. Ha and Jang (2012) explained that the physical environment was important during dining out since it influences judgement on the quality of food and service.

It was noticeable that some appreciated the interior design, layout, decor, colours and decorations. Ha and Jang (2012) revealed that layout and interior design are crucial in enhancing revisit intentions and that perceptions of atmospherics affect behavioural intentions such as repeat visits, thus making restaurant environments critical marketing tools. Dittmet and Griffin (1993) too noted that the decor including the style and layout of interior furnishings as well contributed to the atmosphere of a lodging facility. Countryman and Jang (2006) additionally established that the style, lighting and colour of the lobby had a positive effect on the impression of the lobby. The lobby, which is the first place a guest passes before going to the rooms, plays a very useful role in creating the first impression hence making it an essential aspect of accommodation marketing.

A few further confided that crowding more so at the front desk was a concern since it slowed down service. This somehow conflicts Hwang et al. (2012) claims that crowding at waiting areas of restaurants can create mixed impressions such as inaccessibility and popularity of the restaurant thus impacting on guests' feelings, satisfactions and repeat visits. For instance, crowding in bars can create a feeling of fun and excitement.

Several were concerned about the appearance, behaviour and dressing of other guests. These findings are similar to Nicholls's (2011) who observed that customer interactions going beyond cross cultural ones contribute to the satisfaction of hospitality consumers. He continued to argue that the behaviour and appearance of customers including both verbal and non verbal communication can interfere with the experiences of other customers leading to tension or unique experiences and value such as those experienced in niche, volunteer and cultural tourism or in the interaction between a foreign and domestic tourist.

A number revealed that they would opt for hotels which were conveniently located. Some valued hotels which were located away from noise while others were in favour of areas adjacent to beaches so that they could relax, sunbath and enjoy water sports activities like scuba diving. Few did not like town centres due to congestion and traffic jams. However, several revealed that accessibility could matter less especially when other factors which attracted them to the hotel were satisfactorily addressed except where the guests had used their personal cars to visit and the hotels were not accessible. Such guests felt that it would be inconvenient and costly for them due to damages to their vehicles. A number also explained the value of parking and transportation. A few thought that the hotels ought to have tour guiding facilities for foreigners, and transport to and fro access points such as airports. This supported the assertion that location including parking, convenience, accessibility and transportation from areas like airports and taxi services moreover affect guest satisfaction (Poon \& Low, 2005). The relevance of these findings are clear given that Dortyol, Varinli and Kitapci (2014) likewise discovered that 
parking was important to hospitality guests while Lockyer (2005) equally found that location factors such as prices versus transport costs, needs and looks of the property were essential.

Some identified price, value and cost as major determinants of their purchase decisions. This confirmed Lockyer's (2005) notion and finding that price, which is the relationship between the reason of visit and price paid, budget, price versus location and related costs, affects accommodation choice. Nevertheless, several guests complained of the high prices being charged by the hotels. This is much in line with prior studies such as Sarker, Aimin and Begum (2012) which established that tourists were dissatisfied with the tourism product which they thought was priced too expensively. Pedraja and Yagiie (2001) as well noted that price variations can determine eating out decisions of price searchers. Such customers will for instance target restaurants which offer items at their preferred prices. Although it appeared that most guests were not pleased with the high prices, a number revealed that they preferred paying such prices since they will be well aware of the charges and they will be forced to question the quality of products and services if they were priced cheaply. It therefore seemed likely that customers in high end facilities which offer personalized service will expect to pay more than those in middle level ones.

Several liked hotels which gave them discounts. This confirmed that when customers purchase, they desire value too. Hence, some reasoned that since they would have paid high prices for quality products and services, then they ought to be given maximum value, recognition and appreciation. Ramanathan and Ramanathan (2011) confirmed that value for money (VFM) is the most critical hotel attribute as compared to customer service, room quality, cleanliness, food quality and family friendliness particularly in independent hotels as opposed to chain hotels. Choi and Chu (2000) as well discovered that "value including value for money of food and beverage, value of the rooms, reputable chain hotel and comfortable ambience" influenced the satisfaction levels of guests.

Value is closely linked to quality and can be reflected by the quality of the product and service. Value is also reflected in the price with more valuable service accruing higher prices. Ferrel and Hartline (2010) also established that perceived value is an output of customer benefits and costs. Woodall (2003) as quoted by Mohajerani and Miremadi (2012) described this value as "the personal perception of advantage arising out of customer associated with the offering of an organization". Smith (1995) further stated that "value is perceived when customers' requirements are met at an attractive price". Mohajerani and Miremadi (2012) have shown that the higher the perceived value, the more satisfied the customer is. The findings revealed that the hospitality guest considered value to be more important than the price. This is because value encompasses the price and is perceived from both the price and quality of the product or service. As a result, such a customer will be willing to pay any reasonable price just to get something of high worth. However, CSR was mentioned as another dimension of value for a guest who was biased towards giving back to society.

Security was another major concern for most guests. This was due to threats in the country during the study period. The guests were chiefly concerned about terrorism attacks and hijacking of tourists which they felt could be managed using security personnel, screening and check points. Choi and Chu (2000) already stated that "security factors such as responsible security personnel, loud reliable fire alarms and availability of safe boxes determined the satisfaction levels of guests in hotels". Dortyol et al. (2014) likewise revealed that security and safety were important to these guests.

\section{Conclusion}

How customers perceive the marketing strategies of hotels can influence their purchase decisions. If hotels in Kenya are to enjoy enhanced competitiveness by developing clear marketing strategies, it is necessary that they understand what is important to their customers. The guests, who were interviewed, identified the atmosphere, hospitality, food, facilities, amenities, location, accessibility, price, value, discounts and security as being the key factors behind their purchase decisions. These items should subsequently form the basis of the marketing strategies of four and five star hotels in Kenya.

\section{References}

Alexander, M., Gorman, K. O., \& Wood, K. (2010). Nutritional labelling in restaurants, whose responsibility is it anyway? International Journal of Contemporary Hospitality management, 22(4), 572-579. http://dx.doi.org/10.1108/09596111011042758

Andrews, S. (2010). Hotel front office, a training manual. India: Mc Graw-Hill companies.

Burusnukul, P., Binkley, M., \& Sukalakamala, P. (2011). Understanding tourists' patronage of Thailand foodservice establishments: An exploratory decisional attribute approach. British Food Journal, 113(8), 965-981. http://dx.doi.org/10.1108/00070701111153733 
Choi, T. Y., \& Chu, R. (2000). Levels of satisfaction among Asian and Western travellers. International Journal of Quality and Reliability Management, 2(17), 116-132. http://dx.doi.org/10.1108/02656710010304537

Countryman, C. C., \& Jang, S. (2006). The effects of atmospheric elements on customer impression: the case of hotel lobbies. International Journal of Contemporary Hospitality Management, 18(7), 534-545. http://dx.doi.org/10.1108/09596110610702968

Dittmer, P. R., \& Griffin, G. G. (1993). The dimensions of the hospitality industry, an introduction. USA: Van Nostrand Reinhold.

Dortyol, I. T., Varinli, I., \& Kitapci, O. (2014). How do international tourists perceive hotel quality? An exploratory study of service quality in Antalya tourism region. International Journal of Contemporary Hospitality Management, 3(26), 470-495. http://dx.doi.org/10.1108/IJCHM-11-2012-0211

Elaver, E., Tari, J. J., \& Pereira, J. (2006). Does quality impact on hotel performance? International Journal of Contemporary Hospitality Management, 18(4), 350-358. http://dx.doi.org/10.1108/09596110610665357

Ferrel, O. C., \& Hartline, M. D. (2010). Marketing strategy. USA: Cengage learning.

Goodman, R. J. (1996). The management of service for the restaurant. Irwin-book team.

Ha, J., \& Jang, S. S. (2012). The effects of dining atmospherics on behavioural intentions through quality perceptions. Journal of Services Marketing, 26(3), 204-215. http://dx.doi.org/10.1108/08876041211224004

Hwang, J., Bendle, L. J., \& Yoon, S. (2012). Desired privacy and the impact of crowding on customer emotions and approach-avoidance responses. Waiting in a virtual reality restaurant. International Journal of Contemporary Hospitality Management, 24(2), 224-250. http://dx.doi.org/10.1108/09596111211206150

Jani, D., \& Han, H. (2011). Investigating the key factors affecting behavioural intentions: Evidence from a full-service restaurant setting. International Journal of Contemporary Hospitality Management, 23(7), 1000-1018. http://dx.doi.org/10.1108/09596111111167579

Jeffries, D. (2001). Governments and tourism. UK: Butterworth-Heinemann.

Jones, P., \& Dent, M. (1994). Improving service: Managing response time in hospitality operations. International Journal of Operations and Production Management, 14(5), 52-58. http://dx.doi.org/10.1108/01443579410056795

Josiam, B., \& Foster, C. (2009). Nutritional information on restaurant menus: who cares and why restaurateurs should bother, International Journal of Contemporary Hospitality Management, 21(7), 876-891. http://dx.doi.org/10.1108/09596110910985331

Kandampully, J. (2006). The new customer-centred business model for the hospitality industry. International $\begin{array}{lllll}\text { Journal of Contemporary Hospitality } & \text { Management, } & 18(3), & \text { 173-187. }\end{array}$ http://dx.doi.org/10.1108/09596110610658599

Kara, A., Kaynak, E., \& Kucukemiroglu, O. (1995). Marketing strategies for fast-food restaurants: a customer view. International Journal of Contemporary Hospitality Management, 7(4), 16-22. http://dx.doi.org/10.1108/09596119510146823

Knight, A. J., Worosz, M. R., \& Todd E. C. D. (2007). Serving food safety: customer perceptions of food safety at restaurants. International Journal of Contemporary Hospitality Management, 19(6), 476-484. http://dx.doi.org/10.1108/09596110710775138

Kombo D., \& Tromp D. (2006). Proposal and thesis writing. Nairobi: Paulines Publications Africa.

Lockyer, T. (2002). Business guests' accommodation selection: the view from both sides. International Journal of Contemporary Hospitality Management, 14(6), 294-300. http://dx.doi.org/10.1108/09596110210436832

Lockyer, T. (2005). Understanding the dynamics of the hotel accommodation purchase decision. International Journal of Contemporary Hospitality Management, 17(6), 481-492. http://dx.doi.org/10.1108/09596110510612121

Mohajerani, P., \& Miremadi, A. (2012). Customer satisfaction modelling in hotel industry: a case of Kish Island in Iran. International Journal of Marketing Studies, 4(3), 134-152. http://dx.doi.org/10.5539/ijms.v4n3p134

Namkung, Y., Jang, S., Almanza, B., \& Ismail, J. (2009). Identifying the underlying structure of perceived service fairness in restaurants. International Journal of Contemporary Hospitality Management, 21(4), 375-392. http://dx.doi.org/10.1108/09596110910955659 
Negi, J. (2002). Marketing and sales strategies for hotels and travel trades. New Delhi: S. Chand \& Company Ltd.

Nicholls, R. (2011). Customer-to- customer interactions (CCI): a cross-cultural perspective. International

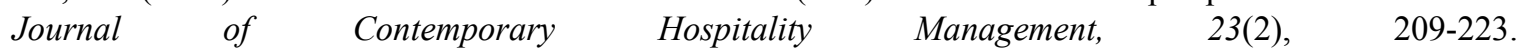
http://dx.doi.org/10.1108/09596111111119338

Page, S. J. (2006). Tourism management. Managing for change. Oxford: Elsevier Butterworth-Heinemann.

Pedraja, M., \& Yagiie, J. (2001). What information do customers use when choosing a restaurant? International Journal of Contemporary Hospitality Management, 13(6), 316-318. http://dx.doi.org/10.1108/EUM0000000005966

Poon, W., \& Low, K. L. (2005). Are travellers satisfied with Malaysian hotels? International Journal of Contemporary Hospitality Management, 17(3), 217-227. http://dx.doi.org/10.1108/09596110510591909

Ramanathan, U., \& Ramanathan, R. (2011). Guest's perceptions on factors influencing customer loyalty: An analysis for UK hotels. International Journal of Contemporary Hospitality Management, 23(1), 7-25. http://dx.doi.org/10.1108/09596111111101643

Sarker, M. A. H., Aimin, W., \& Begum, S. (2012). Investigating the impact of marketing mix elements on tourists' satisfaction: An empirical study on East Lake. European Journal of Business and Management, $4(7)$.

Smith, S. (1995). World-class competitiveness. Managing service quality, 5(5), 36-42. http://dx.doi.org/10.1108/09604529510100387

The Kenya Gazette. (2003). Vol. CV-No. 62. Authority of the Republic of Kenya.

Walter, U., Edvardsson, B., \& Ostrom, A. (2012). Drivers of customer service experiences: a study in the restaurant industry. Managing Service Quality, 20(3), 236-258. http://dx.doi.org/10.1108/09604521011041961

\section{Copyrights}

Copyright for this article is retained by the author(s), with first publication rights granted to the journal.

This is an open-access article distributed under the terms and conditions of the Creative Commons Attribution license (http://creativecommons.org/licenses/by/3.0/). 